\title{
PENERAPAN BLENDED LEARNING BERBANTUAN GEOGEBRA SEBAGAI MEDIA PEMBELAJARAN MATEMATIKA UNTUK MENINGKATKAN HASIL BELAJAR GEOMETRI SISWA SEKOLAH DASAR KELAS V
}

Oleh

\author{
${ }^{1}$ Kadek Yudista Witraguna; ${ }^{2}$ Ni Nyoman Tri Wahyuni \\ ${ }^{12}$ UHN I Gusti Bagus Sugriwa \\ yudistawitraguna@uhnsugriwa.ac.id; triwahyuni@uhnsugriwa.ac.id
}

Diterima 22 April 2021, direvisi 30 Juni 2021, diterbitkan 1 Oktober 2021

\begin{abstract}
Abstrak
Penelitian ini bertujuan untuk memperbaiki proses pembelajaran matematika di Kelas V SD Negeri Hindu 4 Batuan dan meningkatkan hasil belajar geometri siswa Kelas V SD Negeri Hindu 4 Batuan melalui penerapan Blended Learning berbantuan GeoGebra sebagai media pembelajaran. Penelitian ini merupakan Penelitian Tindakan Kelas yang terdiri dari tahap perencanaan, pelaksanaan tindakan, observasi dan evaluasi, serta tahap refleksi. Subjek penelitian ini adalah siswa kelas V SD Negeri Hindu 4 batuan yang terdiri dari 28 siswa dengan objek penelitian yaitu hasil belajar geometri siswa. Hasil penelitian menunjukkan rata-rata hasil belajar geometri siswa meningkat dari 70,2 menjadi 80,5 dan ketuntasan belajar meningkat dari $67,9 \%$ menjadi $85,7 \%$. Siswa memberikan tanggapan positif terhadap penerapan Blended Learning berbantuan GeoGebra sebagai media pembelajaran dengan rata-rata 62,9. Penerapan Blended Learning berbantuan GeoGebra mampu meningkatkan hasil belajar geometri siswa Kelas V SD Negeri Hindu 4 Batuan karena Blended Learning memberikan kesempatan pada siswa untuk belajar mandiri melalui media GeoGebra yang telah disediakan, siswa tetap memperoleh bimbingan langsung oleh guru melalui pembelajaran tatap muka menggunakan video conference, dan media GeoGebra dapat membantu siswa mengeksplorasi objek geometri yang dipelajari.
\end{abstract}

Kata Kunci: Blended Learning, GeoGebra, Hasil Belajar

\begin{abstract}
This study was carried out to improve the mathematics learning process and the geometry learning outcomes of $5^{\text {th }}$ grade students at SD Negeri Hindu 4 Batuan (State Elementary School Hindu 4 Batuan) using Blended Learning combined with GeoGebra as learning media. This Classroom Action Research was conducted through several states including the planning stage, implementation stage, observation and evaluation stage, and the reflection stage. Subjects were 28 fifth grade students of SD Negeri Hindu 4 Batuan. The objects of this study is students' learning outcomes of geometry topic. The results showed that the average score improved from 70.2 to 80.5 and their learning mastery increased from $67.9 \%$ to $85.7 \%$. Students' responses toward the application of Blended Learning using GeoGebra as a learning medium were positive with an average value of of 62.9. The application of GeoGebra-assisted
\end{abstract}


Blended Learning was successful in improving the geometry learning outcomes of the $5^{\text {th }}$ grade students at SD Negeri Hindu 4 Batuan for it allowed students to learn autonomously using GeoGebra media. At the same time, students were still directly guided by the teacher through face-to-face video conferencing, while GeoGebra helped them explore the geometric objects being studied.

\section{Keyword: Blended Learning, GeoGebra, learning outcomes}

\section{PENDAHULUAN}

Pembelajaran matematika tidak terlepas dari media pembelajaran karena media pembelajaran dapat membantu proses interaksi antara guru dan siswa (Khairani, 2016). Melalui media pembelajaran matematika, penyampaikan pesan akan lebih jelas dan mudah dipahami oleh siswa sehingga mampu meningkatkan motivasi dan minat belajar siswa (Purwanti, 2015). Dengan demikian penting bagi guru untuk memilih media yang tepat dan sesuai dengan materi dan karakteristik siswa untuk menciptakan pembelajaran yang bermakna.

Geometri merupakan salah satu aspek dalam matematika yang dibelajarkan di sekolah dasar kepada siswa. Dalam mempelajari geometri, siswa sering mengalami kesulitan mempelajari objek geometri yang bersifat abstrak. Agar objek geometri yang abstrak dapat diamati secara langsung oleh siswa saat pembelajaran berlangsung, objek geometri perlu diwujudkan menjadi bentuk semi konkrit maupun konkrit (Yeni, 2011). Dengan demikian siswa sangat membutuhkan media pembelajaran ataupun alat peraga geometri untuk memahami konsep-konsep geometri. Sebagai contoh, guru sering menggunakan alat peraga berupa model kubus yang terbuat dari kertas karton untuk digunakan dalam pembelajaran sehingga siswa mudah memahami konsep tentang kubus.

Situasi pandemi COVID-19 menyebabkan pendidikan di Indonesia dilaksanakan melalui pendidikan jarak jauh. Berdasarkan surat edaran Nomor 4 tahun 2020 pada tanggal 24 maret 2020 Tentang Pelaksanaan Kebijakan Pendidikan dalam Masa Darurat Peyebaran COVID-19 proses pembelajaran dilaksanakan dirumah melalui daring atau jarak jauh tanpa bertatap langsung dengan siswa dengan tujuan untuk mencegah penyebaran virus COVID-19 dan pembelajaran diharapkan tetap memberikan pengalaman belajar yang bermakna bagi siswa. Namun pada kenyataannya pembelajaran jarak jauh menyebabkan guru dan siswa mengalami banyak kendala dalam pembelajaran (Kemdikbud, 2020). Dalam Penyesuaian Kebijakan Pembelajaran di Masa Pandemi COVID-19 (Kemdikbud, 2020) disebutkan beberapa kendala yang dihadapi oleh guru dan siswa dalam pembelajaran. Kendala yang dihadapi Guru yaitu: (1) Guru kesulitan mengelola pembelajaran jarak jauh, (2) waktu pembelajaran berkurang, (3) Guru kesulitan berkomunikasi dengan orang tua sebagai mitra di rumah. Sedangkan kendala yang dihadapi siswa yaitu : (1) siswa kesulitan konsentrasi belajar dari rumah , (2) siswa mengeluhkan beratnya penugasan soal dari guru, (3) peningkatan rasa stress dan jenuh akibat isolasi berkelanjutan berpotensi menimbulkan rasa cemas dan depresi bagi anak.

Berdasarkan hasil observasi dan wawancara dengan guru kelas V di SD Negeri Hindu 4 Batuan, ditemukan bahwa hasil belajar siswa pada materi bangun datar redah. Ini dapat dilihat dari rata-rata nilai yang peroleh siswa kelas V di SD Negeri Hindu 4 Batuan pada penilian harian untuk materi pokok bangun datar adalah 61,4. Dari 28 siswa, yang memenuhi KKM hanya 7 siswa atau ketuntasan belajar hanya 25\%. Rendahnya hasil belajar siswa dikarenakan (1) pembelajaran daring yang dilaksanakan di SD Negeri Hindu 4 Batuan 
menyebabkan guru kesulitan memberikan model geometri seperti model bagun datar dan bangun ruang yang dapat dilihat, dipegang dan dimanipulasi oleh siswa secara langsung; (2) pembelajaran di SD Negeri Hindu 4 Batuan sebagian besar dilaksanakan melalui google classroom dan aplikasi whatsapp. Guru hanya memberikan materi dalam bentuk power point dan tugas memalui google classroom atau grup whatsapp dan siswa mengumpulkan tugas melalui google classroom atau grup whatsapp sehingga kurangnya interaksi antara guru dengan siswa; (3) model geometri yang diberikan pada siswa disajikan dalam bentuk power point, sehingga siswa hanya dapat melihat model geometri tersebut tanpa dapat memanipulasinya secara langsung untuk mengeksplorasi, menemukan dan memahami konsep objek geometri yang dipelajari.

Untuk meningkatkan hasil belajar geometri siswa kelas V SD Negeri Hindu 4 Batuan, diperlukan perbaikan pembelajaran dan media pembelajaran atau alat peraga geometri yang sesuai dengan pembelajaran daring yang dilaksanakan di SD Negeri Hindu 4 Batuan. Diperlukan alat peraga geometri yang dapat digunakan secara online oleh siswa dan dapat dimanipulasi oleh siswa untuk mempelajari konsep geometri yang dipelajari sepertihalnya alat peraga konvensional. Pembelajaran harus bersifat student centered, namun tetap memperoleh bimbingan dari guru secara langsung walaupun dilaksanakan secara online. Salah satunya guru dapat memanfaatkan aplikasi computer, yaitu aplikasi GeoGebra, dalam membuat alat peraga geometri.

GeoGebra adalah perangkat lunak matematika pendidikan sumber terbuka, dengan jutaan pengguna di seluruh dunia yang memiliki sejumlah fitur seperti integrasi aljabar komputer, geometri dinamis dan spreadsheet (Botana et al., 2015). Dengan menggunakan GeoGebra, guru dapat membuat berbagai bentuk bangunan geometri baik bangun datar maupun bangun ruang yang menarik dan mudah diamati sehingga siswa tertarik untuk belajar. Penggunaan GeoGebra dalam pembelajaran dapat meningkatkan prestasi belajar siswa dan siswa juga memiliki persepsi positif terhadap software GeoGebra dalam hal antusiasme, kepercayaan diri, dan motivasi (Arbain \& Shukor, 2015). Selain itu berdasarkan hasil penelitian (Syofran, 2019), penerapan GeoGebra sebagai media pembelajaran matematika, mampu memberikan hasil belajar siswa yang lebih baik dibandingkan dengan pembelajaran konvensional.

Pembelajaran matematika secara daring yang akan diterapkan di SD Negeri Hindu 4 Batuan harus dapat dikombinasikan secara efektif dengan media GeoGebra dimana siswa dapat belajar secara mandiri namun guru tetap dapat mendampingi, membimbing dan mensilitasi siswa dalam belajar sehingga mampu menyelesaikan permasalahan pembelajaran matematika yang dihadapi. Pembelajaran matematika harus berlangsung secara interaktif, inspiratif, menyenangkan, menantang dan memotivasi siswa untuk berpartisipasi aktif, serta memberikan ruang yang cukup bagi prakarsa, kreativitas dan kemandirian sesuai dengan bakat, minat dan perkembangan fisik serta psikologis social (Gumilang et al., 2019). Salah satu pembelajaran yang dapat diterapkan oleh guru dalam pembelajaran daring agar interaksi antara peserta didik dan pendidik terjalin dengan baik yaitu Blended Learning.

Blended Learning adalah pembelajaran yang manggabungkan pembelajaran tatap muka di dalam kelas dengan pembelajaran online yang memanfaatkan teknologi informasi dan bersifat fleksibel (Syarif, 2013). Melalui Blended Learning siswa dapat belajar secara dinamis dan fleksibel, dimana siswa difasilitasi untuk belajar secara mandiri sehingga siswa dapat mengulang dan menggali lebih jauh tentang materi yang dipelajari dengan bantuan teknologi secara online (Gusmawan \& Priatna, 2020). Penelitian yang dilakukan oleh (Galang et al., 2016) menunjukkan penerapan Blended Learning memberikan hasil belajar siswa yang lebih 
baik dibandingkan siswa yang memperoleh pembelajaran konvensional. Penelitian (Dewi, 2019) menunjukkan adanya peningkatan rata-rata hasil belajar siswa dalam pembelajaran matematika melalui Blended Learning berbasis aplikasi GeoGebra, Google Classroom dan Quizziz. Menurut (Gusmawan \& Priatna, 2020) GeoGebra sangat cocok untuk digunakan sebagai media dalam metode Blended Learning, karena fitur GeoGebra yang dapat menyimpan data berbentuk HTML membuat pembelajaran yang telah dibuat dapat dibagikan kepada pengguna tanpa perlu mendownload aplikasi GeoGebra. Dengan demikian Blended Learning berbantuan GeoGebra sangat relevan diterapkan untuk meningkatkan hasil belajar siswa.

\section{METODE}

Penelitian ini merupakan Penelitian Tindakan Kelas yang bertujuan untuk memperbaiki proses pembelajaran dan meningkatkan hasil belajar geometri siswa Kelas V SD Negeri Hindu 4 Batuan dengan menerapkan Blended Learning berbantuan GeoGebra sebagai media pembelajaran. Subjek dalam penelitian ini adalah siswa kelas V SD Negeri Hindu 4 Batuan tahun ajaran 2020/2021 yang berjumlah 28 orang. Objek dalam penelitian tindakan kelas ini adalah hasil belajar geometri siswa kelas V SD Negeri Hindu 4 Batuan. Adapun tahapan dalam penelitian tindakan kelas ini yaitu berupa siklus yang terdiri dari (1) perencanaan (planing), (2) pelaksanaa tindakan (action), (3) observasi dan evaluasi (evaluation), dan (4)tahap refleksi (reflection). Setiap siklus dilaksanakan dengan empat kali pertemuan dimana tiga kali pertemuan untuk pelaksanaan tindakan dan satu kali pertemuan untuk melaksanakan tes akhir siklus. Instrumen penelitian yang digunakan dalam penelitian ini yaitu tes tertulis dan angket. Tes tertulis berbentuk tes uraian yang digunakan untuk memperoleh data hasil belajar siswa dan diberikan pada setiap akhir siklus. Angket digunakan untuk mengumpulkan data tanggapan siswa terkait penerapan pembelajaran Blended Learning berbantuan GeoGebra.

Data hasil belajar geometri siswa diklasifikasikan berdasarkan kriteria ketuntasan minimal (KKM) mata pelajaran matematika kelas V SD Negeri Hindu 4 Batuan yaitu 70. Ratarata hasil belajar geometri siswa dikategorikan berdasarkan Tabel 1.

Tabel 1. Kriteria Ketuntasan Hasil Belajar

\begin{tabular}{|l|c|l|}
\hline No & Hasil Belajar & Kategori \\
\hline 1 & $0 \leq \bar{X}<70$ & Belum Tuntas \\
\hline 2 & $70 \leq \bar{X} \leq 100$ & Tuntas \\
\hline
\end{tabular}

Sumber : ( KKM di SD Negeri Hindu 4 Batuan,2021)

Keterangan:

$\bar{X}=$ Rata-rata hasil belajar geometri siswa

Data tanggapan siswa terhadap Blended Learning berbantuan GeoGebra dianalisis berdasarkan rata-rata skor $(\overline{\boldsymbol{R}})$, mean ideal $(\boldsymbol{M I})$ dan standar deviasi $(\boldsymbol{S D I})$. Berikut kriteria tanggapan siswa terhadap Blended Learning berbantuan GeoGebra.

Tabel 2. Kriteria Tanggapan Siswa Terhadap Blended Learning Berbantuan GeoGebra

\begin{tabular}{|l|l}
\hline Kriteria & Rentang Skor \\
\hline
\end{tabular}




\begin{tabular}{|l|c|}
\hline Sangat Positif & $\bar{R} \geq 72$ \\
\hline Positif & $54 \leq \bar{R}<72$ \\
\hline Cukup Positif & $36 \leq \bar{R}<54$ \\
\hline Kurang Positif & $18 \leq \bar{R}<36$ \\
\hline Sangat Kurang Positif & $\bar{R}<18$ \\
\hline
\end{tabular}

Sumber : (hasil analisis $\overline{\boldsymbol{R}}, \boldsymbol{M I}$ dan $\boldsymbol{S D I}, 2021)$

Penerapan Blended Learning berbantuan GeoGebra dikatakan berhasil apabila memenuhi kriteria yaitu (1) Rata-rata hasil belajar siswa berada pada kategori tuntas, (2) Ketuntasan Belajar (KB) minimal 80\%, dan (3) tanggapan siswa terhadap Blended Learning Berbantuan GeoGebra minimal dalam kriteria positif.

\section{PEMBAHASAN}

Secara umum pelaksanaan Blended Learning berbantuan GeoGebra di Kelas V SD Negeri Hindu 4 Batuan berlangsung sesuai dengan perencanaan pembelajaran yang telah disusun. Penelitian dilaksanakan untuk pokok bahasan bangun ruang kubus dan balok. Pembelajaran berlangsung secara online dengan menerapkan Blended Leaning berbantuan Geogebra. Materi pembelajaran disampaikan melalui google classroom yang diitegrasikan dengan GeoGebra. Sedangkan pembelajaran tatap muka menggunakan aplikasi video conference Zoom Meetings.

Pada siklus I pembelajaran terdiri dari empat pertemuan dengan kompetensi dasar pengetahuan yaitu menjelaskan, dan menentukan volume bangun ruang dengan menggunakan satuan volume (seperti kubus satuan) serta hubungan pangkat tiga dengan akar pangkat tiga, sedangkan kompetensi dasar ketrampilan yaitu menyelesaikan masalah yang berkaitan dengan volume bangun ruang dengan menggunakan satuan volume (seperti kubus satuan) yang melibatkan pangkat tiga dan akar pangkat tiga. Dipertemuan keempat dilaksanakan tes untuk memperoleh data hasil belajar geometri siswa. Berdasarkan hasil analisis data pada siklus I nilai rata-rata hasil belajar geometri siswa adalah 70,2 dengan ketuntasan belajar 67,9\% atau dari 28 siswa, terdapat 19 siswa yang memenuhi kategori tuntas. Data ini menunjukkan bahwa rata-rata hasil belajar siswa berada pada kategori tuntas namun ketuntasan belajar berada dibawah kriteria yaitu dibawah $80 \%$. Sehingga perlu dilakukan perbaikan proses pembelajaran pada siklus II.

Berdasarkan hasil observasi peneliti bersama guru matematika yang mengajar di Kelas V SD Negeri Hindu 4 Batuan selama tindakan pada siklus I terungkap kendala atau hambatan yang perlu dicermati dalam penerapan Blended Learning berbantuan GeoGebra untuk dijadikan bahan refleksi pada siklus II terkait dengan proses pembelajaran yang berpengaruh pada hasil pembelajaran yang dicapai siswa. Secara umum, permasalahan yang muncul yaitu (1) Siswa belum terbiasa menggunakan GeoGebra sebagai media pembelajaran, dimana aktifitas belajar siswa dilakukan melalui media GeoGebra dalam memahami konsep geometri yang dipelajari. Beberapa siswa terlihat kurang paham dalam penggunaan GeoGebra walaupun sudah disediakan petunjuk penggunaan media; (2) beberapa siswa kesulitan mengakses GeoGebra karena keterbatasan jaringan internet yang digunakan; (3) terdapat siswa yang memiliki keterbatasan alat belajar online seperti handphone dan leptop. Untuk mengatasi kendala tersebut, peneliti menyediakan video yang menjelaskan penggunaan media GeoGebra tahap demi tahap, sehingga siswa dapat memahami cara menggunakan media GeoGebra yang 
digunakan. Untuk mengatasi keterbatasan signal, guru memberikan video dan media GeoGebra secara offline kepada siswa sehingga siswa dapat lebih mudah dalam belajar. Peneliti bersama guru matematika yang mengajar di Kelas V SD Negeri Hindu 4 Batuan melakukan pendekatan secara individual kepada beberapa siswa terkait kendala-kendala belajar yang dialami oleh siswa tersebut selama proses pembelajaran yaitu kendala keterbatasan signal dan perangkat belajar online. Terkait dengan kesulitan-kesulitan atau kendala-kendala yang dialami oleh siswa tersebut, guru selanjutnya memberikan bimbingan dan solusi-solusi alternatif sehingga siswa tersebut dapat melaksanakan proses belajarnya lebih optimal untuk memperoleh hasil yang optimal.

Pelaksanaan tindakan siklus II disesuaikan dengan hasil refleksi pada siklus I dengan melakukan beberapa tindakan perbaikan agar pembelajaran berjalan optimal dan memberikan peningkatan hasil belajar. Pada siklus II pembelajaran terdiri dari empat pertemuan dengan kompetensi dasar pengetahuan yaitu menjelaskan dan menemukan jaring-jaring bangun ruang sederhana (kubus dan balok) sedangkan kompetensi dasar ketrampilan yaitu membuat jaringjaring bangun ruang sederhana (kubus dan balok). Dipertemuan keempat dilaksanakan tes untuk memperoleh data hasil belajar geometri siswa serta diberikan angket untuk mengumpulkan data tanggapan siswa terkait penerapan pembelajaran Blended Learning berbantuan GeoGebra. Berdasarkan hasil analisis data pada siklus II nilai rata-rata hasil belajar geometri siswa adalah 80,5 dengan ketuntasan belajar 85,7 \% atau dari 28 siswa terdapat 24 siswa yang sudah memenuhi kriteria tuntas. Data tersebut menunjukkan bahwa pada siklus II masih terdapat siswa yang belum mencapai KKM atau belum memenuhi kategori tuntas, namun secara keseluruhan terjadi peningkatan hasil belajar geometri siswa. Dengan demikian hasil belajar siswa sudah sesuai dengan harapan dalam penelitian ini. Indikator keberhasilan hasil belajar siswa jika rata-rata hasil belajar siswa berada pada kategori tuntas dan ketuntasan belajar (KB) minimal 80\%.

Tanggapan siswa dalam pembelajaran pada siklus II dikumpulkan berdasarkan angket yang diberikan pada akhir siklus II. Berdasarkan hasil analisis skor tanggapan siswa, diperoleh rata-rata tanggapan siswa sebesar 62,9 atau berada pada kategori Positif. Sebaran nilai tanggapan siswa pada masing-masing kategori yang telah ditetapkan ditunjukkan Tabel 3 berikut:

Tabel 3. Sebaran Skor Tanggapan Siswa

\begin{tabular}{|c|c|c|c|c|}
\hline No. & Rentang Skor & Frekuensi & $\begin{array}{c}\text { Persentase } \\
(\mathbf{\%})\end{array}$ & Kategori \\
\hline 1. & $\bar{R} \geq 72$ & 4 & 14,3 & Sangat Positif \\
\hline 2. & $54 \leq \bar{R}<72$ & 22 & 78,6 & Positif \\
\hline 3. & $36 \leq \bar{R}<54$ & 2 & 7,1 & Cukup Positif \\
\hline 4. & $18 \leq \bar{R}<36$ & 0 & 0 & Kurang Positif \\
\hline 5. & $\bar{R}<18$ & 0 & 0 & Sangat Kurang Positif \\
\hline
\end{tabular}

Sumber : (data dari hasil angket tanggapan siswa, 2021)

Dari hasil siklus I dan siklus II dapat dilihat bahwa terjadi peningkatan rata-rata hasil belajar geometri siwa pada siklus II sebesar 14,7 \% jika dibandingkan dengan hasil belajar geometri siswa pada siklus I yaitu meningkat dari 70,2 menjadi 80,5. Selain itu, ketuntasan belajar meningkat dari $67,9 \%$ menjadi $85,7 \%$ atau meningkat $17,8 \%$. Berdasarkan Tabel 3 dapat dilihat bahwa sebagian besar siswa yaitu 78,6 \% memberikan tanggapan positif dan 14,3 
$\%$ memberikan tanggapan sangat positif terhadap penerapan Blended Learning berbantuan GeoGebra, sedangkan hanya $7,1 \%$ yang memberikan tanggapan cukup positif. Ini menunjukkan bahwa penerapan Blended Learning berbantuan GeoGebra sudah sesuai dengan harapan pada penelitian ini yaitu rata-rata tanggapan siswa terhadap penerapan Blended Learning berbantuan GeoGebra berada pada kategori positif. Dengan demikian dapat dikatakan indikator keberhasilan telah dicapai yaitu rata-rata hasil belajar siswa mencapai kategori tuntas, ketuntasan belajar (KB) lebih dari 80\% dan tanggapan siswa terhadap penerapan Blended Learning berbantuan GeoGebra berada pada kategori positif.

Berdasarkan hasil observasi peneliti bersama guru matematika Kelas V SD Negeri Hindu 4 Batuan pada pelaksanaan siklus I dan II, terjadinya peningkatan hasil belajar geometri siswa pada penelitian ini disebabkan oleh beberapa faktor yaitu: (1) media GeoGebra mampu memvisualisasikan objek geometri yang bersifat abstrak sehingga memudahkan siswa mengeksplorasi objek geometri yang dipelajar, selain itu siswa lebih tertarik dan termotivasi dalam belajar. Seperti yang disampaikan oleh (Arbain \& Shukor, 2015) bahwa penggunaan GeoGebra dalam pembelajaran membuat siswa lebih antusias dalam belajar, meningkatkan kepercayaan diri dan motivasi; (2) Penerapan Blended Learning berbantuan GeoGebra selain memberikan kesempatan pada siswa untuk belajar mandiri melalui media GeoGebra yang telah disediakan, siswa tetap memperoleh bimbingan langsung oleh guru melalui pembelajaran tatap muka menggunakan video conference, sehingga pembelajaran bersifat student cendered yang mampu meningkatkan hasil belajar siswa. Seperti yang disampaikan oleh (Dewi, 2019) bahwa penerapan Blended Learning berbasis multi aplikasi (GeoGebra, Google Classroom dan Quizziz) mampu meningkatkan aktivitas siswa dalam pembelajaran yang berimbas pada peningkatan hasil belajar siswa; (3) Perbaikan proses pembelajaran pada siklus II berdasarkan kendala yang dihadapi pada sikus I menyebabkan pembelajaran berjalan lebih optimal, dimana peran guru adalah memfasilitasi siswa yang memiliki kendala dalam penerapan Blended Learning berbantuan GeoGebra untuk memberikan bimbingan dan solusi-solusi alternatif sehingga siswa tersebut dapat melaksanakan proses belajarnya lebih optimal.

Penerapan Blended Learning berbantuan GeoGebra mampu meningkatkan hasil belajar geometri siswa, namun ada beberapa kendala yang dihadapi dan perlu menjadi pertimbangan dalam penerapan Blended Learning berbantuan GeoGebra, yaitu: (1) dalam pembelajaran diperlukan jaringan internet yang stabil, sehingga pembelajaran bisa berjalan baik, dimana dalam penelitian ini ditemukan beberapa siswa terkendala karena akses internet; (2) dalam pembelajaran siswa membutuhkan perangkat seperti handphone dan leptop sebagai sarana belajar, dimana tidak semua siswa memiliki perangkat yang cukup untuk digunakan dalam pembelajaran; (3) tidak semua siswa mampu menggunakan GeoGebra dengan baik, sehingga guru perlu membuat video yang menunjukkan cara penggunaan media GeoGebra yang digunakan untuk dapat ditonton oleh siswa sebelum mulai belajar menggunakan media GeoGebra.

\section{SIMPULAN}

Berdasarkan hasil analisis data dan pembahasan, dapat disimpulkan bahwa: (1) penerapan Blended Learning berbantuan GeoGebra mampu meningkatkan hasil belajar geometri siswa Kelas V SD Negeri Hindu 4 Batuan karena Blended Learning memberikan kesempatan pada siswa untuk belajar mandiri melalui media GeoGebra yang telah disediakan, siswa tetap memperoleh bimbingan langsung oleh guru melalui pembelajaran tatap muka menggunakan video conference, dan media GeoGebra dapat membantu siswa mengeksplorasi objek geometri 
yang dipelajari; (2) tanggapan siswa terhadap penerapan Blended Learning berbantuan GeoGebra adalah positif; (3) terdapat beberapa kendala yang perlu menjadi pertimbangan dalam penerapan Blended Learning berbantuan GeoGebra.

\section{DAFTAR PUSTAKA}

Arbain, N., \& Shukor, N. A. (2015). The Effects of GeoGebra on Students Achievement. Procedia - Social and Behavioral Sciences, 172(2007), 208-214. https://doi.org/10.1016/j.sbspro.2015.01.356

Botana, F., Hohenwarter, M., Janičić, P., Kovács, Z., Petrović, I., Recio, T., \& Weitzhofer, S. (2015). Automated Theorem Proving in GeoGebra: Current Achievements. Journal of Automated Reasoning, 55(1), 39-59. https://doi.org/10.1007/s10817-015-9326-4

Dewi, D. A. (2019). Pembelajaran Matematika Melalui Blended Learning Berbasis Multi Aplikasi Sebagai Strategi Menghadapi Era Revolusi Industri 4.0. Jurnal Ilmiah Kependidikan, 14, 27-32.

Galang, A., Suryaningtiyas, W., \& Kristanti, F. (2016). Penggunaan Model Pembelajaran Blended Learning terhadap Hasil Belajar Matematika Kelas VIII di SMPN 38 Surabaya. MUST: Journal of Mathematics Education, Science and Technology, 1(1), 10. https://doi.org/10.30651/must.v1i1.97

Gumilang, M. R., Wahyudi, \& Indarini, E. (2019). Pengembangan Media Komik dengan Model Problem Posing untuk Meningkatkan Kemampuan Pemecahan Masalah Matematika. Journal of Medives, 3(2), 185-196.

Gusmawan, D. M., \& Priatna, N. (2020). Pengembangan Bahan Ajar Model Pembelajaran Blended Learning Berbantuan Geogebra untuk Meningkatkan Kemampuan Berpikir Kritis Matematis Siswa SMA. Edsence: Jurnal Pendidikan Multimedia, 2(2), 93-100. https://doi.org/10.17509/edsence.v2i2.22871

Kemdikbud. (2020). Penyesuaian Kebijakan Pembelajaran di Masa Pandemi COVID-19. Www.Kemdikbud.Go.Id.

https://www.kemdikbud.go.id/main/blog/2020/08/kemendikbud-terbitkan-kurikulumdarurat-pada-satuan-pendidikan-dalam-kondisi-khusus

Khairani, M. (2016). Pengembangan Media Pembelajaran Dalam Bentuk Macromedia Flash Materi Tabung Untuk SMP Kelas IX. Jurnal Iptek Terapan, 10(2), 95-102. https://doi.org/10.22216/jit.2016.v10i2.422

Purwanti, B. (2015). Pengembangan Media Video Pembelajaran Matematika dengan Model Assure. Jurnal Kebijakan Dan Pengembangan Pendidikan, 3(1), 42-47. http://ejournal.umm.ac.id/index.php/jmkpp/article/view/2194

Syarif, I. (2013). Pengaruh model blended learning terhadap motivasi dan prestasi belajar siswa SMK. Jurnal Pendidikan Vokasi, 2(2), 234-249. https://doi.org/10.21831/jpv.v2i2.1034

Syofran, A. H. (2019). Pengaruh Penggunaan Media Geogebra Terhadap Hasil Belajar Siswa Pada Materi Grafik Fungsi Trigonometri. Jurnal Mathematic Paedagogic, 4(1), 84. 
ADI WIDYA: Jurnal Pendidikan Dasar FAKULTAS DHARMA ACARYA UNIVERSITAS HINDU NEGERI I GIJSTI RAGI IS SIJGRIWA
Volume. 6, Nomor 2 Oktober 2021

ISSN: 2685-8312 (online)

ISSN: 2527-5445 (cetak

http://ejournal.ihdn.ac.id/index.php/AW

https://doi.org/10.36294/jmp.v4i1.893

Yeni, E. M. (2011). Pemanfaatan Benda-Benda Manipulatif Untuk Meningkatkan Pemahaman Konsep Geometri Dan Kemampuan Tilikan Ruang Siswa Kelas V Sekolah Dasar. Edisi Khusus, 1, 63-75. http://jurnal.upi.edu/file/7-Ety_Mukhlesi_Yeni.pdf 